Vol. 7, n² | 2003

Varia

\title{
Policing in East Germany in the wake of the Second World War
}

Richard Bessel

\section{(2) OpenEdition \\ Journals}

Electronic version

URL: https://journals.openedition.org/chs/539

DOI: $10.4000 /$ chs.539

ISSN: 1663-4837

Publisher

Librairie Droz

Printed version

Date of publication: 1 December 2003

Number of pages: $5-21$

ISBN: 2-600-008990-3

ISSN: $1422-0857$

\section{Electronic reference}

Richard Bessel, "Policing in East Germany in the wake of the Second World War", Crime, Histoire \& Sociétés / Crime, History \& Societies [Online], Vol. 7, n² | 2003, Online since 25 February 2009, connection on 22 March 2022. URL: http://journals.openedition.org/chs/539 ; DOI: https://doi.org/ $10.4000 /$ chs. 539

This text was automatically generated on 22 March 2022.

(c) Droz 


\title{
Policing in East Germany in the wake of the Second World War
}

\author{
Richard Bessel
}

1 The emergence of Europe from the social, economic, psychological and political rubble of the Second World War forms one of the great defining stories of the twentieth century $^{2}$. Across the continent, Europeans faced the challenge of establishing social and political order in the wake of the vast explosion of violence and destruction which had just occurred. In that part of Germany which fell under Soviet control in 1945 - the Soviet Occupation Zone, then from 1949 the German Democratic Republic - this challenge was particularly difficult. East Germany emerged from Nazism and war to be occupied by the Soviet Army, confronted with economic collapse, flooded with refugees, and overwhelmed by crime, with German state institutions abolished, the population traumatised by violence, and half its young men either dead or in prisonerof-war camps. While western Germany generally had suffered more from Allied bombing than did what became the Soviet Occupation Zone, the latter contained not only some of the most thoroughly devastated cities - most prominently, Magdeburg and Dresden - but also wide swathes of countryside and numerous small towns which had been laid waste during the ferocious battles of the last weeks of war. The result was a landscape of ruins, a site of almost unimaginable economic collapse, social upheaval and human misery.

2 This landscape of ruins provided a most unpromising base from which to begin the task of re-establishing order in what would become the German Democratic Republic. Some idea of what faced the German 'anti-fascists' who arrived in the wake of the Red Army and were charged with rebuilding administrative structures, can be gained from an 'activity report' for the period May-November 1945 filed by the Landrat of the District of Demmin, in Pomerania (not far from the new border to Poland):

On 15 May 1945, after the Red Army had marched in on 30 April 1945, I was confirmed [as Landrat] by the [Soviet] war commandant. The district, above all the town of Demmin, had suffered particularly heavy damage. 365 houses, roughly 70 per cent of the town, lay in ruins, over 700 inhabitants had ended their lives by suicide. Everywhere there was rubble and debris. As any coordinated direction of 
the regional government and of government authorities was lacking, I had to take charge in all areas and in all branches of the administration, naturally in agreement with the commandant.

All branches of the district administration had to be reconstructed, and new office space had to be found and furnished, as most of the [government] records had been destroyed. At first it was necessary to provide the population, especially the inhabitants of the three towns [of the district], including the many refugees, with food and to accommodate the homeless. Accordingly, the greatest concern involved agriculture, in order to ensure that the fields were cultivated and the harvest brought in. [...]

While at first a few former members of the Nazi Party had to be taken on as skilled workers, they nevertheless soon were removed from all public offices and from leading positions in the economy and replaced by antifascists. In order to get economic life moving again, I restored the three branch railway lines in the district. Unfortunately they were dismantled after a short period. [...]

Great difficulties arose with the industrial enterprises, as these had been either largely destroyed or dismantled by commandos of the Red Army. [...]. One attempted to get all production started again by the most elementary means.

Bringing in the harvest and threshing the grain gave us great difficulties, as most of the machines had been confiscated and most of the horses had been driven away. By calling up all available labour the work nevertheless was accomplished, and the delivery quota was met, despite all the damage caused us by what the Red Army took without payment and without receipt, for example from 72 communities: 1,767 cattle, 896 pigs, 4,106 sheep, 32 calves, 2,221 chickens, 100,997 eggs, 282 geese and 142,200 kilograms of grain. [...]

In the district there are now about 54,000 refugees, whose accommodation and feeding creates ever greater difficulties. [...]

The spread of typhus is due primarily to the insufficient nourishment and [resulting] debilitation. [...] An examination of all inhabitants between 15 and 45 years of age for venereal disease has been ordered and will be carried out with the help of police control points. [...]

The mood of the population is for the most part solemn and depressed. There are complaints about insufficient distribution of food. In addition the lack of clothing and footwear, especially among the resettlers [i.e. refugees], is especially noticeable with the onset of the cold weather. We have not yet received any of the promised allocations.

The accommodation of the resettlers creates particular difficulties. To the roughly 53,000 inhabitants of the district 54,000 resettlers have been added already. They were put up [first] in transit camps in the district and then distributed among the villages, since the commandant has prohibited migration into the towns ${ }^{3}$.

The challenges which such conditions posed for any attempt to establish social order and construct a new political and economic order in postwar East Germany, and for the new police force which would bear a major share of the responsibility for enforcing that order, were enormous. The once-vaunted German bureaucracy largely had ceased to function by May 1945, and the resources available to those who had to get the administrative machinery moving again were minimal; the German 'antifascists' put into posts by the Soviet military had to deal first with a bureaucracy inherited from the hated Nazi regime and then with the lack of trained personnel once the old guard had been removed; in the northern portions of the Soviet Occupation Zone, including the district of Demmin, half the population were homeless and destitute refugees from east of the new Oder-Neiße border (in the Zone as a whole the proportion was about a quarter) ${ }^{4}$; attempts to get production moving and to feed the population were seriously undermined by the actions (both official and unofficial) of the Soviet military, which ranged from dismantling railways and factories to stealing livestock and personal 
property - and to raping a substantial proportion of the German female population; and an undernourished and often ill population looked on sullenly as the Soviet occupiers and their German placemen took over what remained of German government offices.

In the description of conditions in Demmin quoted above, the police were mentioned only once: they were expected to help carry out checks on adults for venereal disease. This is not because policing was unimportant in postwar Germany; during a period of extreme social upheaval and disorder and high levels of crime, and when East Germany's new masters were determined to remove 'fascists' from positions of power and responsibility in general and from police ranks in particular, the creation of a politically reliable and operationally competent police force was a major concern. However, in the immediate aftermath of the German defeat, the new East German 'People's Police' (Volkspolizei) comprised a small, mostly unarmed and largely ineffective force. Initially the task of imposing order, of a sort, fell to the Red Army whose soldiers, of course, also caused widespread fear and disorder by assaulting, raping, and stealing from the Germans under their control. It is hardly surprising that, initially, neither the Soviet military authorities nor the German Communists (many of whom had suffered at the hands of German police under the Nazis) were prepared to trust a German police force very far with the task of law enforcement. So soon after the Gestapo had exercised its reign of terror and German police units had killed tens of thousands of innocent civilians in eastern Europe, allowing German police to check people for venereal disease was one thing, equipping (and arming) them so that they might effectively combat crime - much of which was being committed by Soviet soldiers - was quite another.

5 Nevertheless, soon after the Soviet military had taken control of what became the Soviet Occupation Zone and later the German Democratic Republic, Germans began to be given responsibility for public order and security. Local officials - the mayors and Landräte placed in their posts by the Russians - were delegated the task of setting up local police forces ${ }^{6}$. The new police recruits were drawn as far as was possible from the ranks of 'proven anti-fascists' - veterans of the labour movement, workers who were known to have supported the Communists; people who had worked in the police formations of the Nazi regime were removed. The men placed in charge of the new 'People's Police' were determined to make a sharp break with the Nazi past, to root out 'fascists' in this most sensitive and important sphere, and to put policing in East Germany on a new footing appropriate to the new political era. Georg König, Chief of the Police in the Province of Saxony, put it thus in May 1946:

The police in the new democratic state is in its essence and in its tasks something different than what it was in the Nazi state, which had to maintain its terror regime precisely through the police, especially the 'Secret State Police' [Gestapo]. Today the police really shall be the helper and protector of all sections of the people who are well-intentioned and willing to engage in rebuilding. It must become a People's Police in the best sense of the word ${ }^{7}$.

Similarly, in August 1946 Hans Kahle, the Chief of Police in the Land MecklenburgVorpommern, wrote to all members of his force:

In the new democratic state coming into being, the member of the police is the servant of the German people. It is to the people that he is to devote all his powers, all his abilities and knowledge. Therefore his relationship to the individual among the people is not one of a superior to an inferior but one of a carer and counsellor to whom the population should turn in confidence with its needs, cares and concerns ${ }^{8}$. 
7 Such declarations should not be dismissed as mere cynical propaganda or self-delusion on the part of the committed Communists who headed the police after 1945. There existed a genuine desire to put policing on a revolutionary new footing, and to replace the disorder which followed from Germany's disastrous war and defeat with a new, 'progressive' political order. Of course, a 'People's Police in the best sense of the word' was not supposed to be politically neutral; it was clear to all concerned that the Volkspolizei would be a 'helper' only to those people who were 'well-intentioned and willing to engage in rebuilding'. Those who might have been otherwise inclined, who allied themselves or were seen to ally themselves - or were seen as likely to ally themselves - with the 'class enemy', could expect rather different treatment.

But this is getting a bit ahead of ourselves. After May 1945 the recruitment of a police who the German Communists and their Soviet masters felt they could trust led to the almost complete replacement of the police personnel in the Soviet Zone, and opened the Volkspolizei to people almost none of whom ever had been in police uniform before. Internal statistics compiled with obsessive energy on the composition of the police during the post-war years confirm that, as the German Administration of the Interior estimated in its 'Annual Report for 1946-1947', 'over 90 per cent of the members of the police in the Soviet Occupation Zone are people from outside the profession [berufsfremde Menschen]'. The statistics which the German Administration of the Interior compiled for June 1947, for example, show that of the 39,683 recorded members of the Volkspolizei in the Soviet Zone, only 2101 (6.0\%) had worked in the police before 1945 and a further $940(2.7 \%)$ before $1933^{10}$. These statistics frame a remarkable picture: of a police force with almost no continuity from the past, which had broken completely with traditional sources of police recruitment (for example, sons of policemen and the military), and whose new members could not easily learn to behave like police officers by observing the conduct of more experienced colleagues. For the first time in modern German history, a police force was created with an almost completely new membership and which represented a radical break with the past ${ }^{11}$.

This police force faced a remarkable set of challenges. In a society which had experienced the most profound social and political upheaval - with most of its cities and wide stretches of its countryside destroyed, much of its population homeless refugees, a large proportion of its young men dead or in prisoner-of-war camps and a large proportion of its women raped, without adequate food supplies, emerging from the complete destruction of the German state power and the absolute moral bankruptcy of National Socialism, and occupied by a foreign armed force - the natural desire was for a return to some semblance of security and normality ${ }^{12}$. Times of extreme upheaval produce extreme longing for stability and normality. However, that stability and normality comprised precisely what was denied the inhabitants of the Soviet Occupation Zone and then the German Democratic Republic. Instead, in the years following the destruction of the 'Third Reich', East Germany was forced down a path of political and economic transformation of far-reaching proportions. Rather than let the people under their control rebuild their lives in peace, East German Communists (supported by the Soviet occupiers) imposed a regime of continual mobilisation and upheaval. The upheaval of war, defeat and occupation was followed by the upheaval of a Stalinist political revolution. continued upheaval and a people who, for the most part, wanted just the opposite. The 
new police formations were in an extraordinarily difficult position: they were largely inexperienced and untrained; they had to deal with day-to-day policing problems which were, in the immediate postwar years, enormous; their powers to enforce the law were initially greatly circumscribed by the Soviet Military Administration (which had the final say when it came to policing); they were regarded with scepticism, to say the least, by a large proportion of a population which was unfavourably disposed to both Soviet-inspired socialism and the Soviet occupiers; they were charged with protecting and enforcing a political order which, in essence, was imposed by an enemy occupation force and its domestic allies; and their political masters felt a deep distrust of a population (including the working class) which only a few years before had supported Hitler so enthusiastically ${ }^{13}$. What is more, immediately after the war the new East German police force was quite small and had few resources at its disposal. In January 1946 the total personnel (both male and female, including clerical staff) of the German police in the Soviet Occupation Zone was a mere 21,973 - or just over one police officer per one thousand inhabitants ${ }^{14}$. Even in an orderly society this would have been a rather small number; it is less than the total (roughly 27,400 ) employed in 2001 by the police in Berlin alone ${ }^{15}$. What this meant on the ground may be illustrated by the situation in, once again, the rural Pomeranian district of Demmin, where in August 1945 the police numbered only 85 people in a district containing roughly 90,000 inhabitants ${ }^{16}$. Given that, at best, only about half of these police would have been on duty at any one time, the rather sparse nature of policing in East Germany immediately after the war is evident, at least in so far as German (as opposed to Soviet) police personnel is concerned.

11 In almost every respect the German police forces in the Soviet Zone faced crippling problems in the first two years of their existence. As noted above, the new police recruits were almost completely inexperienced, having been chosen for political reliability rather than professional competence or previous service in police formations (something which usually served to disqualify people for employment in the newlyformed Volkspolizei) ${ }^{17}$. They tended to be relatively old, since trusted 'anti-fascists' often were either Social Democrats or Communists from the Weimar period or people who had had some experience of underground or trade-union activity, and thus were older than the sorts of people normally recruited into a police force; the fact that immediately after the war most of Germany's young men were either dead or in prisoner-of-war camps left the Volkspolizei little alternative. According to internal statistics on the personnel structure of the police throughout the Soviet Zone in June 1947, 31.8\% of the Schutzpolizei (i.e., the regular police who performed the everyday tasks of policing on the beat) as a whole, and fully $30.5 \%$ of the rank-and-file, were over 40 years old ${ }^{18}$. As the head of the police in Bitterfeld explained in October 1946, 'many tested anti-fascists, who came from workshops and factories', initially had been taken into the new force, and 'these were in many cases older comrades whose mental abilities were not sufficient to master service in the police ${ }^{19}$. Many had joined the force neither out of political conviction nor out of some altruistic desire to serve the public but primarily in order to gain food (ration cards), clothing (uniforms, boots) and shelter (police barracks) during a time of terrible shortages, and many were underweight and prone to illness ${ }^{20}$, which was hardly surprising given the miserable conditions in postwar Germany. Almost none had had any specific training for their new job. Even after police training schools had been set up in all the east German Länder, following the opening of the first such school in Saxony in March 1946, only a 
small proportion could be schooled in their new profession quickly; in April 1947 Walter Mickinn, Head of the Personnel Section of the German Administration of the Interior, reported that in Thuringia 'roughly 65\%' of the police still had not received training, in Brandenburg 70\%, and in Sachsen-Anhalt and Mecklenburg the figure was $94 \%$ and $95 \%$ respectively ${ }^{21}$. The newly-hired recruits frequently adopted a decidedly casual approach to their duties, and they often proved to be ill-disciplined and/or corrupt; cases of drunkenness and theft among the 'People's Police' were common ${ }^{22}$. Altogether, this was not a police force in a particularly good condition to impose order on a profoundly disordered society.

Matters were complicated further by the fact that the new People's Police were extremely poorly equipped. Initially the Allies prohibited the German police from carrying firearms, and not until 1946, after the Allied Control Council lifted the ban (in January), did the Soviet occupation authorities permit the bulk of the German police in their zone to be $\operatorname{armed}^{23}$. Nevertheless, and despite the urgings of the German Communist leadership (and of Walter Ulbricht in particular), even in late 1946 only 30 per cent of the personnel of many police units had firearms. This made it all but impossible for them effectively to confront armed criminals, at a time when there were substantial numbers of illegal arms at large, and bred what was described by the Volkspolizei leadership as 'a passivity within the police which can have catastrophic consequences for public order and security ${ }^{24}$. The police possessed few if any motor vehicles, and even bicycles were a rarity (and bicycle tyres difficult to acquire), making the idea of police mobility little more than a joke; indeed, as late as October 1948 the Volkspolizei in Sachsen-Anhalt complained that, because the police lacked bicycles and bicycle tyres, they were in no position to protect farmers' fields effectively from thieves who had bicycles and therefore were 'far better equipped than the police officers chasing them ${ }^{25}$. The police authorities possessed little or nothing in the way of working telecommunications equipment, since the telephone network had been wrecked during the war in large sections of the Zone and since the Soviet authorities initially did not allow the German police radio communication; not until 1947 did they permit the German police to get their own telex network ${ }^{26}$. This meant that during the first couple of years after the war it was virtually impossible for police stations to communicate quickly with one another or for local commanders to communicate with their superiors or subordinates. This in turn made it all the more difficult to impose and maintain discipline and good working practices throughout police ranks, and it is hardly surprising that, in such circumstances, clear-up rates for crime initially were disappointingly low ${ }^{27}$.

13 Additional problems stemmed from the Soviet military presence itself. The new police forces often found themselves caught between the concerns of a population which nominally they existed to protect and the demands and actions of the Soviet military to which they ultimately were responsible. During the immediate postwar period, Soviet soldiers were a major source of crime, which began with the orgy of rape and other violence which accompanied their arrival in Germany in the winter and spring of 1945 and which continued to make the Soviet Occupation Zone a very dangerous place long after the German surrender. Not just the civilian population but members of the police forces too became targets for the violence of the occupier, and those German police who attempted to intervene in cases where Russian soldiers raped German women risked arrest or being shot ${ }^{28}$. During the postwar years the rise and fall of violent crime, often by armed 'bandits' who frequently were Soviet soldiers or deserters, were 
mirrored in the numbers of casualties among the Volkspolizei: from May to December 194537 Volkspolizisten were killed in violent incidents; in 1946 the number rose to 87; while in 1947 the number dropped to 26 (although by this time the total number of German police in the Soviet Zone had risen substantially ${ }^{29}$. At the same time, German police were expressly forbidden from using firearms against Soviet soldiers no matter what the provocation - a ban which continued in force once the Volkspolizei was well armed in the late 1940s. This even was spelled out publicly: in 1948 in the new illustrated journal, Die Volkspolizei, members of the Volkspolizei were informed in no uncertain terms that 'use of weapons must never and under no circumstances be made against members of the occupation forces ${ }^{30}$. Effectively, in one of the most important areas of policing, i.e. dealing with violent crime, the hands of the Volkspolizei were tied.

This left economic crime as a main focus for police work, hardly surprising given the dreadful economic problems confronting almost all Germans after the war. Dreadful shortages, rampant inflation, a thriving black market, and the division of Germany into separate economic zones created numerous opportunities to engage in economic crime. Consequently, the day-to-day activities of the police were directed in large measure towards combating the black market throughout the Soviet Zone and the smuggling which was rampant across the demarcation line with the western occupation zones of Germany ${ }^{31}$. The police constantly mounted raids (for example, at railway stations) in order to throttle black-market trading and arrest the perpetrators of a crime which not only undermined economic order but also provided socialists with the worst example of unbridled free enterprise, and in rural districts the 'main task' for the police was enforcing the mandatory delivery of farm produce ${ }^{32}$. However, while such campaigns were fully compatible with the political aims of the German Communist leadership and the Soviet authorities, they also complicated the relationship of the 'People's Police' with the people it was supposed to serve. What the people desired - physical security above all - the police could not yet deliver; and what the police could and did provide often was not exactly what was desired by a population which had to evade controls and to resort to illegal commerce in order to acquire basic necessities. Comments drafted in early 1947 by the Volkspolizei leadership about popular attitudes towards the police gives a sense of the predicament faced in this regard by the German forces of law and order in the Soviet Zone:

The unpopularity of the police is not accounted for only by unsatisfactory personnel policies, social difficulties and shortcomings (in statutes, schooling, etc.), but also has its causes in the present-day economic situation of the population.

The police very frequently are compelled to intervene against small-scale hoarders [Klein-Hamsterer], who are trying to improve their diet by buying additional food. The police are encouraged to confiscate even the smallest amounts. Since the population for the most part has no appreciation of this, these measures by the police are regarded as unjust. It has even happened that hoarders and people stealing from fields have carried out attacks on the police and the organisations helping them ${ }^{33}$.

15 The 'People's Police' thus were caught between the demands of their Soviet and German Communist masters and of their job on the one hand, and a widely-held popular sense of justice and injustice on the other ${ }^{34}$. At a time of severe shortages and great material hardship, and in a territory occupied by a foreign military force for which there was little affection, the 'People's Police' inevitably aroused the hostility of the people. This effectively undermined the hopes, however genuinely felt, of leading 
figures who had founded the Volkspolizei, that the new police force would be one to which 'the population should turn in confidence with its needs, cares and concerns' 35 .

The disquiet which unpopular policing duties aroused was not confined to the civilian population. It also surfaced among the police themselves, where resentment about having to do the bidding of the foreign occupying power was widely felt. This was compounded by the fact that a large proportion of German police manpower had to be devoted to guarding Soviet installations and Soviet-controlled factories - manpower which then was unavailable for protecting the interests and ensuring the safety of the German civilian population ${ }^{36}$. Thus, for example, in August 1947 a leading member of the district committee of the Socialist Unity Party in Cottbus (where in the spring of 1947 the demands of the Soviet authorities had left only about a quarter of the police available to see to the needs of the German population) observed in an internal report about the condition of the local police that there existed within police ranks 'generally a negative attitude towards the Russian occupation force': 'Not infrequently there are cases in which police officers, including those in senior positions, react to requests of the Russian occupation force by saying, why should we do work for the Russians, they also steal from us ${ }^{37}$. More than in any other field of their activity, in their dealings with the Soviet military the 'People's Police' found themselves in the uncomfortable position of having to transgress popular opinion. The fundamental contradictions facing a 'People's Police' which was to be 'of the people, for the people's8 and which had to enforce a political order imposed on a defeated and resentful people, was plain even to the police themselves.

In addition to combating economic crime amidst the postwar shortages and to patrolling the streets in order to prevent, as far as was possible for a small largely unarmed force, burglaries, robberies and assaults, the Volkspolizei had other responsibilities. Among the first tasks allotted to the new local police formations once they had been called into being in 1945 was setting up functioning 'Residents Registration Offices' (Einwohnermeldeämter) and registering the local inhabitants ${ }^{39}$. At a time when typewriters and paper were in extremely short supply this was not easy, and was made all the more difficult by the fact that a large proportion of the population of the Soviet Zone consisted of refugees whose papers could not be found and whose background (and supposed political reliability) could not be checked. Another task, and one which assumed a steadily growing importance for the Volkspolizei, was the suppression of political dissent. Already during its first years of operation the Volkspolizei was becoming preoccupied with the need to suppress all signs of political opposition, such as the 'distribution of leaflets with fascist slogans' ${ }^{\prime 40}$. In the years to come, as the immediate problems of policing a chaotic postwar society ebbed, this field of activity would grow substantially; as crime fell and the numbers of police rose, more and more attention was devoted to the need to expose and root out 'saboteurs' and 'agents' allegedly working for the class enemy to the west.

18 One area of work which now soaks up a major proportion of police resources was still a relatively a minor concern for the Volkspolizei in its early years, however: dealing with motor-vehicle traffic and accidents. There was rather little civilian traffic in the Soviet Zone; much of the traffic (and accidents) on East German roads involved the Soviet military; and the German police themselves had hardly any motor vehicles at their disposal. The task of directing traffic in the cities and towns was allotted in large measure to women who had been recruited into the new police force, a sign perhaps of 
its secondary importance ${ }^{41}$. Other tasks performed by female members of the Volkspolizei were of more obvious importance, in particular their involvement in campaigns to combat prostitution and venereal disease, which were significant concerns in the immediate postwar years.

19 Although the Volkspolizei was conceived of in clearly political terms from the outset, policing social and political upheaval immediately after the war meant for the most part dealing with everyday concerns. Initially at least, the more serious and overtly political matters were dealt with by the Soviet military and secret police apparatus ${ }^{42}$. However, as it grew and developed against the background of the increasingly bitter Cold War externally and of Stalinisation internally, the Volkspolizei became steadily more political in its approach to policing. Already by the summer of 1947 the idea that 'the police has nothing to do with politics, [that] the police must remain unpolitical' had become a target for derision and cause for the concern of East German Communists with responsibility for 'justice and police' ${ }^{\prime 43}$. During the years which followed, the Volkspolizei leadership made clear time and again that this police force was to be explicitly political. Criminality and the efforts to combat it, as well as the behaviour of individuals within the Volkspolizei, were to be assessed against political criteria and from a 'class standpoint'. As an officer of the Thuringian Volkspolizei put it at a conference at the end of 1949: 'Police work is party work. One cannot separate these concepts' ${ }^{\prime 4}$. The 'People's Police' were not expected to be impartial enforcers of the law. New recruits had to swear their oath of allegiance recognising 'that the Volkspolizei was created in order to protect the interests of the working people from all fascist, reactionary and other elements which are enemies of the working people ${ }^{\prime 45}$. The 'People's Police' were expected explicitly to side with the 'progressive' forces of the new anti-fascist-democratic, then socialist order against the forces of reaction. This expectation reflected not so much a need to deal with the social upheaval created by the catastrophes of war, Nazism and occupation as it did a determination to carry out a revolutionary political transformation. Any pretence of impartial policing was abandoned, as the Volkspolizei diverged ever more starkly from the politically neutral model of policing to which at least lip service is paid in pluralist political systems. As East German Police Chief Karl Maron put it in a well-publicised speech in February 1953, 'the Volkspolizei can never be «neutral» or «unpolitical»" ${ }^{46}$.

The overt politicisation of the Volkspolizei paralleled the physical transformation of the organisation, as the new 'People's Police' did not remain small, decentralised or illequipped for very long. A process of rapid expansion already had begun by mid-1946, when the German Administration of the Interior was created by (secret) order of the Soviet Military Administration: the total number of German police in the Soviet Occupation Zone rose from 21,973 in January 1946 to 38,767 in July 1947, 54,729 in April 1948, 68,148 in September 1948 and to 83,178 (including the 18,229 members of the Border Police - Grenzpolizei - and the paramilitary Bereitschaften) in March $1949^{47}$. It would be mistaken to assume that this remarkable growth was primarily a response to high levels of crime; indeed, the ordinary police formations - the Schutzpolizei, the police officers who patrolled the streets of East Germany - were the formations which grew least quickly. Rather, the number of police rose as crime fell; the postwar crime wave peaked in late 1946/early 1947, and during 1947 and 1948 recorded crime diminished in the Soviet Zone ${ }^{48}$ - precisely when the Volkspolizei was expanding most rapidly. The motives for this expansion of the police were largely political, and it occurred at least partly at the insistence of the Soviet Military Administration, which 
was concerned to see the Germans take over security tasks - under Soviet supervision of course. Thus the Border Police were created in November 1946 at the order of the Soviet authorities, who wanted the Germans to help patrol the border with the western occupation zones, and 1948 saw the creation of the paramilitary Bereitschaften, which formed the kernel of what eventually became the East German National People's Army. In any event, the impetus for the growth and militarisation of the East German police appears to have been not a concern about the security needs of the civilian population but rather a determination to secure political control as the Cold War came to dominate European political life.

21 Control of a reliable and effective police force was crucial to the imposition of a political and economic system which lacked the support of a large proportion of the population and, later, to the creation of a new East German military establishment. This is what lay behind the far-reaching changes which the Volkspolizei underwent during the crucial year of 1948. With the urgent problems of the immediate postwar period now past, the intensification of the Cold War and the transformation of the Socialist Unity Party into a party of a 'new type' was reflected in a transformation of the police in the Soviet Occupation Zone which involved reorganisation and purges. In July 1948 Kurt Fischer (who had spent the war in the USSR and who then had served as Minister of the Interior in Saxony) was named President of the German Administration of the Interior and Chief of the German People's Police (replacing Erich Reschke); and during the summer of 1948 'Political Culture' (Polit-Kultur) sections designed to enforce ideological conformity and discipline were introduced into the Volkspolizei, mirroring developments elsewhere in the growing east German administration and following the model established in the Soviet military and police forces ${ }^{49}$. Until his sudden death in June 1950, after which command of the Volkspolizei fell to Karl Maron, Fischer worked energetically to turn the east German police into a thoroughly centralised, politicised and increasingly militarised force. Behind Fischer stood Walter Ulbricht: it is clear that, right from the beginning Ulbricht was the driving force among the German communists in the Soviet Zone and possessed an authority far greater than that of his comrades, especially in matters involving the all-important area of security and policing. Ulbricht's main concern clearly was not alleviating the effects of social upheaval; he was focused single-mindedly on securing, maintaining and increasing political power.

The nature of the police and of policing changed rapidly in East Germany during the late 1940s. The ad hoc approach which had characterised the establishment of the new police forces immediately after the war was replaced by ever tighter central control and political and ideological discipline. By early 1948 Ernst Melsheimer, who later became the Chief Public Prosecutor of the German Democratic Republic, could boast at a conference of the Committee on Legal Questions with the Central Secretariat of the Socialist Unity Party that 'we have control of the police' ('Die Polizei hat man in der Hand') $)^{50}$. As the police grew larger, better equipped and more powerful, the focus on everyday policing matters was relegated behind an ever greater emphasis on the political purpose of the 'People's Police'. Initial preoccupation with the day-to-day concerns of a civil society in a state of considerable social upheaval was overshadowed by the militarisation of the Volkspolizei, as the Soviet occupation authorities entrusted more and more security tasks to their German Communist allies, and by the development of what later was to become the vast secret-police empire of the Stasi ${ }^{51}$. Against the background of an increasingly bitter Cold War and the Stalinisation of the 
East German political system, the 'People's Police' became a thoroughly politicised, centralised, militarised force. The Volkspolizei was to be, as Heinz Hoffmann (at that time Deputy Chief of the Volkspolizei and later, from 1960 until his death in 1985, East German Minister of Defence) wrote in the magazine Die Volkspolizei in February 1950, 'the bearer of arms of our democratic order' whose primary task was 'to protect the Republic from all the schemes of her enemies' ${ }^{\prime 2}$. It was an organisation for which the fact that someone might have scribbled 'Russki go home' on a provincial Soviet memorial became a major concern ${ }^{53}$. By the time the German Democratic Republic had been founded, the primary task of the 'People's Police' was to support and enforce a political transformation being directed from the centre and secure the new socialist order against 'agents and saboteurs'.

When looking back over the role of the Volkspolizei during the immediate postwar years, perhaps the most striking thing about how social and political upheaval was policed in East Germany is that there was relatively little effective policing of that upheaval. When the police were most needed by the East German population they were least in a position to do their job effectively; and when they later were in a position to police East German society effectively - as the size of the force rose, as crime ebbed and as the Volkspolizei's clear-up rates for ordinary crime reached levels of which most police forces today would be very proud ${ }^{54}$ - their main purpose was a rather different one. The history of policing in postwar East Germany was not so much of a force which had developed in order effectively to deal with the social and political upheaval of the postwar years, but rather of a passing of the postwar upheaval which allowed for the development of a new, thoroughly politicised type of policing. The task of dealing with the social consequences of the war and the terrible conditions of the postwar years was overshadowed by the political project of East Germany's Communist masters. The purpose of the 'People's Police' was an overtly political one, and one which, in the short term at least, was not exactly crowned with success - as their stunning failure to prevent or suppress the popular uprising of June 1953 demonstrated ${ }^{55}$.

How far the practice of the Volkspolizei diverged from that if the ideal-type of a police force designed in the first instance to serve and protect the population can be seen in a curious interchange between Karl Maron, the Chief of the German People's Police, and the editors of the newspaper Tägliche Rundschau in December 1952. By that time, the upheaval of the immediate postwar period lay years in the past, the Cold War had entered its most bitter phase, and East Germany had been launched by Walter Ulbricht on the precipitate and disastrous campaign to lay 'the foundations of socialism'. Maron had submitted an article to the newspaper about the importance of traffic safety, but the Tägliche Rundschau declined to publish it. Instead the newspaper's editors asked the East German police chief to write a different piece, this one 'on the question of the intensified class struggle in the GDR'. 'We regard it as very important', the newspaper's editorial office wrote, 'that our readers are informed on the basis of concrete examples about the work of the Volkspolizei in the struggle against saboteurs and terrorists especially in the villages - and thus at the same time are educated to be increasingly vigilant and are called upon to help in the task ${ }^{56}$. A dedicated Communist functionary, Maron did as he was asked. The problems of traffic safety would have to give way before the need to combat 'saboteurs and terrorists'. The Volkspolizei was no longer if indeed it ever had been - 'the servant of the German people'; once the postwar 
emergency had passed, it could become what its political masters wanted it to be: an instrument of the Cold War.

\section{BIBLIOGRAPHY}

Benz, W. (Ed.), Deutschland unter alliierter Besatzung 1945-1949/55, Berlin, Akademie Verlag, 1998.

Bessel, R., Polizei zwischen Krieg und Sozialismus. Die Anfänge der Volkspolizei nach dem Zweiten Weltkrieg, in Jansen, C., Niethammer, L., Weisbrod, B. (Eds), Von der Aufgabe der Freiheit. Politische Verwantwortung und bürgerliche Gesellschaft im 19. und 20. Jahrhundert. Festschrift für Hans Mommsen zum 5. November 1995, Berlin, Akademie Verlag, 1995, pp. 517-531.

Bessel, R., The making of a border: policing East Germany's Western border, 1945-1952, in Baechler, C., Fink, C. (Eds.), L'établissement des frontières en Europe après les deux guerres mondiales, Bern, Peter Lang, 1996, pp. 199-214.

Bessel, R., Die Volkspolizei und das Volk. Mecklenburg-Vorpommern 1945 bis 1953, in van Melis, D. (Ed.), Sozialismus auf dem platten Land. Mecklenburg-Vorpommern 1945-1953, Schwerin, Thomas Helms Verlag, 1999, pp. 17-40.

Bessel, R., «Besonders schwierig... weltanschaulich zu schulen». Volkspolizistinnen in der SBZ und frühen DDR 1945-1952, in Fürmetz, G., Reinke, H., Weinhauer, K. (Eds.), Nachkriegspolizei. Sicherheit und Ordnung in Ost- und Westdeutschland 1945-1969, Hamburg, Ergebnisse Verlag, 2001, pp. 155-168.

Bessel, R., The people's police and the people in Ulbricht's Germany, in Major, P., Osmond, J. (Eds.), The Workers' and Peasants' State. Communism and Society in East Germany under Ulbricht 1945-1971, Manchester, Manchester University Press, 2002a, pp. 59-77.

Bessel, R., Leben nach dem Tod. Vom Zweiten Weltkrieg zur zweiten Nachkriegszeit, in Wegner, B. (Ed.), Wie Kriege enden. Wege zum Frieden von der Antike bis zum Gegenwart Paderborn, Ferdinand Schönngh, 2002b, pp. 239-258.

Bessel, R., Schumann, D. (Eds.), Life after Death. Approaches to a Cultural and Social History of Europe during the 1940s and 1950s, Cambridge, Cambridge University Press, 2003.

Buchheim, C., Kriegsschäden, Demontagen und Reparationen. Deutschland nach dem Zweiten Weltkrieg, in Deutscher Bundestag (Ed.), Materialien der Enquete-Kommission «Aufarbeitung von Geschichte und Folgen der SED-Diktatur in Deutschland", vol. ii, no. 2, Baden-Baden, Nomos Verlagsgesellschaft, 1995, pp. 1030-1069.

Bundesministerium der Justiz (Ed.), Im Namen des Volkes? Über die Justiz im Staat der SED. Katalog zur Ausstellung des Bundesministeriums der Justiz, Leipzig, Forum Verlag, 1994.

Diedrich, T., Der 17. Juni 1953 in der DDR, Berlin, Dietz Verlag, 1991.

Foitzik, J., Sowjetische Militäradministration in Deutschland (SMAD) 1945-1949, Berlin, Akademie Verlag, 1999. 
Gieseke, J., Das Ministerium für Staatssicherheit (1950-1990), in Ehlert, H., Wenzke, R. (Eds.), Im Dienste der Partei. Handbuch der bewaffneten Organe der DDR, Berlin, Ch. Links Verlag, 1998, pp. 371-422.

Gieseke, J., Mielke-Konzern. Die Geschichte der Stasi 1945-1990, Stuttgart, Deutsche Verlags-Anstalt, 2001.

Gieseke, J., Ulbricht's secret police: The ministry of state security, in Major P., Osmond, J. (Eds.), The Workers' and Peasants' State. Communism and Society in East Germany under Ulbricht 1945-1971, Manchester, Manchester University Press, 2002, pp. 41-58.

Groehler, G., Antifaschismus - vom Umgang mit einem Begriff, in Herbert, U., Groehler, G., Zweierlei Bewältigung. Vier Beiträge über den Umgang mit der NS-Vergangenheit in den beiden deutschen Staaten, Hamburg, Ergebnisse Verlag, 1992, pp. 29-40.

Grossmann, A., A question of silence: The rape of German women by occupation soldiers, in Robert G. Moeller (Eds.), West Germany under Construction. Politics, Society, and Culture in the Adenauer Era, Ann Arbor, University of Michigan Press, 1997, pp. 33-52.

Hoerning, E., Frauen als Kriegsbeute. Der Zwei-Fronten-Krieg. Beispiele aus Berlin, in Niethammer, L., von Platow, A., (Eds.), 'Wir kriegen jetzt andere Zeiten'. Auf der Suche nach der Erfahrungen des Volkes in nachfaschistischen Ländern, Berlin and Bonn, Verlag J.H.W. Dietz Nachf., 1985, pp. 327-344.

Hoffmann, H., Entscheidend ist das politische Bewußtsein, Die Volkspolizei. Zeitschrift für das gesamte Polizeiwesen, vol. iii, no. 3 (10 Feb. 1950), p. 2.

Karlsch, R., Allein bezahlt? Die Reparationsleistungen der SBZ/DDR 1945-1953, Berlin, Ch. Links Verlag, 1993.

Lindenberger, T., Aus dem Volk, für das Volk? Bemerkungen zur Entstehung der bewaffneten Organe der SBZ/DDR aus sozialhistorischer Sicht, in Bald, D., Brühl, R., Prüfert, A., (Eds.), Nationale Volksarmee - Armee für den Frieden, Baden-Baden, Nomos Verlagsgesellschaft, 1995, pp. 165-180.

Lindenberger, T., Die Deutsche Volkspolizei (1945-1990)', in Diedrich, T., Ehlert, H., Wenzke, R., (Eds.), Im Dienste der Partei. Handburch der bewaffneten Organe der DDR, Berlin, Ch. Links Verlag, 1998, pp. 97-152.

Maron, K., Auch die Volkspolizei muß von der Sowjetunion lernen, Die Volkspolizei. Zeitschrift für das gesamte Polizeiwesen, vol. 6, no. 4 (February 1953), pp. 1-3.

Ministerium des Innern, Kommission zur Erforschung und Ausarbeitung der Geschichte der Deutschen Volkspolizei (Ed.) Geschichte der Deutschen Volkspolizei, vol. I, 1945-1961 (2nd edn.), Berlin, VEB Deutscher Verlag der Wissenschaften, 1987.

Naimark, N., The Russians in Germany. A History of the Soviet Zone of Occupation, Cambridge, Mass., Harvard University Press, 1995.

von Platow, A. (Ed.), Sowjetische Speziallager in Deutschland 1945 bis 1950. Band 1. Studien und Berichte, Berlin, Akademie Verlag, 1998.

Reinke, R., «Ordnung, Sicherheit und Hilfe». Die Anfänge der Volkspolizei in den sächsischen Großstädten Leipzig und Dresden 1945-1947, in Fürmetz, G., Reinke, H., Weinhauer, K. (Eds.), Nachkriegspolizei. Sicherheit und Ordnung in Ost- und Westdeutschland 1945-1969, Hamburg, Ergebnisse Verlag, 2001, pp. 51-70.

Roth, R., Der 17. Juni 1953 in Sachsen, Cologne and Weimar, Böhlau Verlag, 1999. 
Sander, H., John, B. (Eds.), BeFreier und Befreite. Krieg, Vergewaltigungen, Kinder, Frankfurt am Main, Fischer Taschenbuch Verlag, 1995.

Schneider, D., Innere Verwaltung/Deutsche Verwaltung des Innern (DVdI), in Broszat, M., and Weber, H. (Eds.), SBZ Handbuch. Staatliche Verwaltungen, Parteien, gesellschaftliche Organisationen und ihre Führungskräfte in der Sowjetischen Besatzungszone Deutschlands (2nd edn.), Munich, R. Oldenbourg Verlag, 1993, pp. 207-217.

Suckert, S., Süß, W. (Eds.), Staatspartei und Srtaatssicherheit. Zum Verhältnis von SED und MfS, Berlin, Ch. Links Verlag, 1997.

Wenzke, R., Auf dem Wege zur Kaderarmee. Aspekte der Rekruitierung, Sozialstruktur und personellen Entwicklung des entstehenden Militärs in der SBZ/DDR bis 1952/53, in Thoß, B. (Ed.), Volksarmee schaffen - ohne Geschrei! Studien zu den Anfängen einer 'verdeckten Aufrüstung' in der SBZ/ DDR 1947-1952, Munich, R. Oldenbourg Verlag, 1994, pp. 205-272.

\section{NOTES}

2. On this theme generally, see Bessel, Schumann (2003).

3. Mecklenburgisches Landeshauptarchiv (= MLHA), Kreistag/Rat des Kreises Demmin, Nr. 46, ff. 62-64: [The Landrat des Kreises Demmin] to the Präsident des Landes Mecklenburg-Vorpommern, Abteilung Innere Verwaltung, [Demmin], 21 Nov. 1945, 'Tätigkeitsbericht über die Verwaltung des Kreises Demmin vom Mai bis November 1945'.

4. By comparison, in 1950 refugees comprised roughly one-sixth of the population of the Federal Republic. See Benz (1998, p. 124).

5. On the Soviet dismantling policies, see Karlsch (1993); Naimark (1995, pp. 141-204); Buchheim, (1995, pp. 1051-1056). On rape in 1945, Hoerning, (1985, pp. 327-346); Sander, John (1995); Grossmann, (1997, pp. 33-52); Naimark (1995, pp. 69-140).

6. See, for example, the informative account by the Deputy Mayor of the Pomeranian town of Anklam, who was installed in office in May 1945. See MLHA, Kreistag/Rat des Kreises Anklam, Nr. 39, ff. 29-33: II. Bürgermeister, 'Tätigkeitsbericht für die Zeit vom 7. Mai bis zum 16. Juli 1945', Anklam, 16 July 1945.

7. Landeshauptarchiv Sachsen-Anhalt (=LHS S-A), MdI, Nr. 3021, ff. 44-47: Chef der Polizei, 'Rundererlaß Nr. I', Halle/S., 21 May 1946.

8. MLHA, Landesbehörde der Volkspolizei (=LBdVP), Nr. 9, f. 25: Chef der Polizei des Landes Mecklenburg-Vorpommern an alle Polizisten, Schwerin, 13 Aug. 1946. Generally, Lindenberger (1995, pp. 165-166).

9. Bundesarchiv Berlin (=BAB), DO-1-7. Nr. 23, ff. 42-117 (here f. 49): 'Jahresbericht Deutsche Verwaltung des Innern in der sowjetischen Besatzungszone, 1946-1947'.

10. BAB, DO-1-7, Nr. 138, f. 66: 'Personalstruktur. Monat: Juni 1947'. The highest percentage of those who had been employed in the police before 1945, 15.2\%, was among the Administrative Police. Administrative Police also employed by far the highest percentage of women $(46.0 \%$, as compared with $12.1 \%$ for the Volkspolizei as a whole); it is possible therefore, that a disproportionate number of Volkspolizisten who had worked for the police under the Nazis were female clerical staff.

11. This point has been made before: Bessel (1995, pp. 522-523); Lindenberger (1995, p. 166). See also Reinke (2001, pp. 58-59).

12. On this theme generally, see Bessel (2002b, pp. 239-258); Bessel, Schumann (2003).

13. See the suggestive remarks in Groehler (1992, p. 33).

14. See Wenzke (1994, p. 237); Lindenberger (1998, p. 99). 
15. Der Spiegel, 15 Sept. 2001, p. 50.

16. MLHA, Kreistag/Rat des Kreises Demmin, Nr. 69, ff. 70-1: Kreis- und Ortspolizeibehörde to the Präsident des Landes Mecklenburg-Vorpommern, Demmin, 31 Aug. 1945.

17. See Reinke (2001, p. 58).

18. BAB, DO-1-7, Nr. 138, f. 66: 'Personalstruktur, Monat: Juni 1947'.

19. LHS S-A, LBdVP, Nr. 27, ff. 87-103 (here f. 96): 'Protokoll der Konferenz der Polizeiführer der Schutz- und Landpolizei des Bezirks Merseburg am 26.10.1946 10.00 Uhr in der Provinzialverwaltung, Halle'.

20. See LHA S-A, LBdVP, Nr. 309, f. 178: Kommando der Schutzpolizei, 'Einrichtungen und Maßnahmen zum Schutze der Gesundheit von Polizeiangehörigen', Magdeburg, 3 March 1947.

21. BAB, DO-1-7, Nr. 138, ff. 76-86: Landespolizei Thüringen; BAB, DO-1-7, Nr. 138, ff. 89-94: Landespolizei Sachsen-Anhalt; BA, DO-1-7, Nr. 138, ff. 99-109: Landespolizei Mecklenburg; BAB, DO-1-7, Nr. 138, ff. 112-15: Landespolizei Brandenburg. Even in Saxony, which had been the first East German Land to set up a training school, as late as July 1948 only a little over a quarter of the police had been given training; in Leipzig the figure was a mere $11 \%$. See Reinke (2001, p. 63).

22. LHA S-A, LBdVP, Nr. 27, ff. 87-103: 'Protokoll der Konferenz der Polizeiführer der Schutz- und Landespolizei des Bezirks Merseburg am 26.10.1946 10.00 Uhr, in der Provizialverwaltung, Halle' (here the comments by Colonel Stachanowsky, ff. 87-88); Naimark (1995, pp. 356-357).

23. For example, for the 950 members of the Schutzpolizei in Magdeburg in November 1945 there were only $137.65 \mathrm{~mm}$ pistols available - one for the Commander, eight for the Section Chiefs ('Reviervorsteher'), two for 'keeping watch on the bank', one for 'purposes of training' and one for prisoner transports. See LHS S-A, LBdVP, Nr. 290, ff. 14-15: The Polizeipräsident to the Bezirkspräsident, Magdeburg, 8. Nov. 1945.

24. BAB, DO-1-7, Nr. 364, f. 23: Deutsche Verwaltung des Innern (Reschke and Wagner) to the Sowjetische Militäradministration Deutschlands, Abt. für innere Angelegenheiten, Oberstleutnant Smirnow, Berlin-Wilhelmsruh, [?] November 1946. Generally, see Naimark (1995, p. 357).

25. LHA S-A, MdI, Nr. 4161, f. 129: Landesbehörde to the Minister des Innern, Halle (Saale), 4 Oct. 1948.

26. The Volkspolizei were given permission to set up a telex network in January 1947, but this was not in place and functioning until August of that year. See BAB, DO-1-7, Nr. 19, ff. 42-117 (here f. 74): 'Jahresbericht. Deutsche Verwaltung des Innern in der sowjetischen Besatzungszone, 1946-1947'.

27. Naimark (1995, p. 358).

28. Naimark (1995, p. 116).

29. BAB, DO-1-7, Nr. 169, f. 1: Abteilung P[ersonal], 'Todesfälle von Polizeiangehörigen', to the Präsident [of the Deutsche Verwaltung des Innern] via Vizepräsident Mielke, [Berlin], 2 July 1948. 30. Polizeikommissar F. Boettcher, 'Die Anwendung der Schußwaffe', Die Volkspolizei. Zeitschrift für das gesamte Polizeiwesen, vol. i, no. 7 (September 1948), p. 6.

31. On East-West smuggling and illicit crossing of the demarcation line, see Bessel (1996, pp. 208-213).

32. MLHA, LBdVP, Nr. 283, f. 2: Kreispolizei Grimmen to the Kreiskammandantur in Grimmen, Grimmen, 10 Oct. 1947.

33. BAB, DO-1-7, Nr. 146, ff. 63-64: undated report, probably from the Abteiling P [Personal] of the DVdI, describing conditions in March 1947. Cracking down on black-market trading also could generate popular approval, however, while 'health raids' (e.g. for venereal disease) by police could provoke 'the resistance of the population'. See MLHA, LBdVP, Nr. 283, ff. 73-74: Kreispolizeiamt Grimmen to the Ministerium für Innere Verwaltung und Planung, Abt. Polizei, in Schwerin, Grimmen, 23 Dec. 1947.

34. See Bessel (1999, pp. 30-31). 
35. Thus Hans Kahle, the first postwar Chief of Police in Mecklenburg-Vorpommern. See MLHA, LBdVP, Nr. 9, f. 25.

36. An extreme example is that of the city of Brandenburg, where in the spring of 1947115 of the 130 available regular police officers had to guard Soviet installations. See BAB, DO-1-7, Nr. 138, ff. 112-25: Landespolizei Brandenburg (undated, probably written in April 1947).

37. BAB, DO-1-7, Nr 205, ff. 34-6: Otto Hauschke to the Instrukteur der S.E.D. für die Provinz Brandenburg, Bez. Cottbus, 'Zur Lage in der Polizei', Cottbus, 10 Aug. 1947.

38. This guiding principle was formulated in June 1945 by the new Police President in Berlin, Paul Markgraf. See Lindenberger (1995, pp. 165-166).

39. BAB, DO-1-7, Nr. 270, ff. 36-42: Der Leiter, Hauptsekretariat [der DVdI], to the Leiter der Abteilung S Herrn Vogel, Berlin, 13 Nov. 1947, 'Jahresbericht'.

40. See BAB, DO-1-7, Nr. 146, ff. 165-183: Der Chef der Polizei der Provinz Mark Brandenburg [Staimer], 'Die Lage der Polizei der Provinz Mark Brandenburg', Potsdam, 10 June 1947. It also should be noted that, right from the beginning of its existence, the new East German police were charged with arresting suspected political opponents and handing them over to the Soviet secret police (NKVD). See, for example, MLHA, LBdVP Nr. 424, ff. 19-20: Polizeidienststelle Sassnitz, ‘Tätigkeitsbericht für die Zeit vom 19.-25.11.1945', Sassnitz, 28 Nov. 1945.

41. On women in the Volkspolizei during its early years, see Bessel (2001, pp. 155-167).

42. On the Soviet security apparatus in the SBZ, see von Platow (1998); Foitzik (1999, pp. 161-167). By October 1945 the Soviet NKVD had arrested nearly 100,000 people in the SBZ, 82,000 of whom were Germans. See Foitzik (1999, p. 170).

43. BAB, DO-1-7, Nr. 205, ff. 34-36.

44. BAB, DO-1-7, Nr. 266, ff. 152-169 (here f. 157): Landesbehörde der Volkspolizei, Abteilung Schutzpolizei, 'Protokoll-Notiz über die am 28.12.1949 bei der LBdVP Thüringen stattgefundene Arbeitstagung der Leiter der S.', Weimar, 28 Dec. 1949.

45. BAB, DO-1-7, Nr. 229, f. 26: 'Eidesstattliche Erklärung der VP-Rekruten'.

46. Maron (1953, pp. 1, 3).

47. These figures are not exactly comparable with one another; for example, the 5-6,000 members of the railway police are not included in the figures for 1946-1948. However, the general trend is clear. Figures taken from statistics compiled by the German Administration of the Interior are published in Wenzke (1994, p. 237). See also Lindenberger (1998, p. 99).

48. See Ministerium des Innern (1987, pp. 115-116).

49. Schneider (1993, pp. 212-213).

50. Quoted in Bundesministerium der Justiz (1994, p. 15).

51. This is not the place to go into the history of the Stasi, which grew out of the 'Kommissariat 5' (K5) of the Volkspolizei, the section of the organisation which was responsible for the struggle against the 'opponents of the antifascist-democratic reconstruction' and which worked most closely with the Soviet secret police. The successor to the K5 (when it was dissolved in October 1949), the 'Main Section for the Protection of the Economy and the Democratic Order', was the direct predecessor of the Stasi. On the history of the Stasi, see Suckert, Süß (1997); Gieseke (1998, pp. 371-420; 2001; 2002, pp. 41-58).

52. Hoffmann (1950, p. 2).

53. So in Pasewalk in the spring of 1951. See MLHA, LBdVP, Nr. 15, ff. 156-67 (here f. 159): Landesbehörde der Volkspolizei Mecklenburg, 'Protokoll über die VPKA-Leiter Tagung am 9. Mai 1951 in der LBdVP Mecklenburg', Schwerin, 11 May 1951.

54. In 1947 and 1948, clear-up rates in Mecklenburg, for example, generally were well over 60\%. See the 'Tätigkeitsberichte' and the 'Berichte über die Kriminalität' in BA, DO-1-7, Nr. 366, and the 'Kriminalstatistik' in BAB, DO-1-7, Nr. 367.

55. On the uprising of June 1953 and the failure of the Volkspolizei to suppress it, see Diedrich (1991); Roth (1999); Bessel (2002 a, pp. 69-71). 
56. BAB, DO-1-11, Nr. 132, f. 1: Tägliche Rundschau, Redaktion und Verlag, DDR-Abteilung, to the Chef der Deutschen Volkspolizei Karl Maron, Berlin, 12 Dec. 1952.

\section{ABSTRACTS}

This article focuses on the tremendous upheaval experienced by Germans in the Soviet Occupation Zone after 1945, and how the new 'People's Police' developed during the difficult postwar years. Initially, when the needs of the population for police protection were greatest, the new police force was least able to provide that protection. Lacking sufficient trained personnel, equipment and powers, the Volkspolizei could not really effectively police a profoundly shaken postwar society. However, after the initial emergency had passed, the Volkspolizei grew to become a substantial force, but one whose main purpose was to serve the new political order rather than meet the needs of the population.

Cet article porte sur l'énorme bouleversement qu'ont vécu les Allemands dans la zone d'occupation soviétique après 1945 et sur le développement de la «police populaire» dans les années difficiles de l'après-guerre. C'est dans les premiers temps, alors que la population avait le plus besoin d'une protection policière, que la nouvelle force de police était la moins capable de remplir cette tâche. Manquant de personnel entraîné, d'équipement et de pouvoir, la Volkspolizei ne pouvait accomplir sa mission dans une société d'après-guerre profondément troublée. Toutefois, une fois l'urgence initiale passée, la Volkspolizei devint une organisation d'une puissance considérable, dont la tâche principale, toutefois, était de servir l'ordre nouveau plutôt que de répondre aux attentes de la population.

\section{AUTHOR}

\section{RICHARD BESSEL}

Department of History, University of York, Heslington, York Y010 5DD, UK, rjb8@york.ac.uk Richard Bessel is Professor of Twentieth Century History at the University of York. Among his publications are Germany after the First World War (Oxford, 1993); (ed.) Fascist Italy and Nazi Germany: Comparisons and Contrasts (Cambridge, 1996); and (ed., with Dirk Schumann) Life after Death. Approaches to a Cultural and Social History of Europe during the 1940s and 1950s (Cambridge, 2003). Since 1994 he has been Co-editor of the journal German History. He currently is working on a study of Germany in 1945. 